\title{
Implant ślimakowy z perspektywy osób dorosłych z głuchotą prelingwalną - badanie jakościowe
}

\section{Cochlear implant from the perspective of prelingually deaf adults - a qualitative study}

\author{
Joanna Kobosko ${ }^{1 \mathrm{ABDEF}}$, Agnieszka Pankowska ${ }^{1 \mathrm{DEF}}$, \\ Anna Geremek-Samsonowicz ${ }^{1 D E F}$, Henryk Skarżyński' ${ }^{2 D E G}$ \\ ${ }^{1}$ Instytut Fizjologii i Patologii Słuchu, Światowe Centrum Słuchu, Klinika Rehabilitacji, \\ Warszawa/Kajetany \\ ${ }^{2}$ Instytut Fizjologii i Patologii Słuchu, Światowe Centrum Słuchu, Warszawa/Kajetany
}

\section{Streszczenie}

Wstęp: Implant ślimakowy (ang. Cochlear Implant, CI) odgrywa ważną rolę w życiu osób dorosłych z głuchotą prelingwalną niezależnie od wieku, w którym otrzymały tę elektroniczną protezę słuchu. Poza indywidualnymi wypowiedziami użytkowników CI na ten temat w Polsce jak dotąd nie ma badań jakościowych poświęconych znaczeniu, oraz pozytywnym i negatywnym stronom stosowania CI w tej grupie osób.

Cel: W badaniach postawiono pytanie o znaczenie CI, a także pozytywne i negatywne strony tego urządzenia w percepcji osób dorosłych prelingwalnie ogłuchłych.

Materiał i metoda: Uczestnikami badań byli dorośli z głuchotą prelingwalną zaopatrzeni w CI w okresie dzieciństwa, adolescencji lub dorosłości, którzy odpowiedzieli na ankiety rozesłane drogą pocztową. Stanowią oni grupę n = 28 osób, w tym 20 kobiet i 8 mężczyzn, o wysokich kompetencjach w języku polskim fonicznym. Wskaźnik odpowiedzi zwrotnych wynosi 40\%. Osoby badane odpowiadały na trzy pytania dotyczące: znaczenia CI, pozytywnych i negatywnych jego stron. Wypowiedzi ankietowe zostały poddane analizie jakościowej z wykorzystaniem metody analizy treści (ang. Content Analysis). Wyodrębniono kategorie do analizy otrzymanego materiału treściowego, które pozwoliły na opis, jak spostrzegają znaczenie oraz pozytywne i negatywne strony CI jego użytkownicy z głuchotą prelingwalną.

Wyniki: Okazało się, że znaczenie CI wyraża się jego pozytywną lub bardzo pozytywną waloryzacją i poprawą jakości życia jego użytkowników. Wiąże się to przede wszystkim z możliwością słyszenia za pomocą tego urządzenia, a także mówienia i porozumiewania się z otoczeniem w języku fonicznym. Niektórzy uczestnicy badań doświadczają w związku z CI możliwości rozwoju, poprawy funkcjonowania w relacjach społecznych ze słyszącymi, relacjonują pozytywne emocje odnoszące się do CI. Negatywne strony CI to przede wszystkim eksploatacyjno-techniczne, jak np. częsta zmiana baterii, jak i związane z ograniczeniami w codziennej aktywności, np. sport, czy też dotyczące sfery medycznej, np. niemożność wykonywania wybranych badań, przykładowo rezonansu magnetycznego.

Wnioski: Pozytywna waloryzacja CI przez jego użytkowników z głuchotą prelingwalną pozostaje w zgodności z doniesieniami na ten temat. Zwracają uwagę negatywne strony w percepcji jego badanych użytkowników, zwłaszcza te, które stają się lub mogą się stać przyczyną przerw w działaniu systemu CI jako źródło doświadczanego niepokoju, lęku czy paniki w takich sytuacjach. Różne formy interwencji psychologicznej powinny znaleźć się w ofercie rehabilitacyjnej dla użytkowników CI z tej grupy, by mogli wypracować efektywne strategie radzenia sobie z negatywnymi doświadczeniami związanymi z korzystaniem z CI, jak i skonfrontować się z własną głuchotą.

Słowa kluczowe: implant ślimakowy • głuchota prelingwalna • analiza treści • pozytywne i negatywne strony implantu ślimakowego 


\section{Abstract}

Background: Cochlear implant plays an important role in everyday life of prelingually deaf adults, irrespective of the age at which this type of electronic hearing device was received. Apart from single opinions of CI users concerning this issue, there have not been any qualitative studies discussing the significance as well as positive and negative aspects of cochlear implant use in this group of patients performed in Poland so far.

Aim: The aim of this study was to discuss the significance of CI use as well as the advantages and disadvantages of this type of hearing device from the perspective of prelingually deaf adults.

Material and method: The study included prelingually deaf adults with cochlear implants received in the period of childhood, adolescence or adulthood, who responded to the questionnaires sent to them by post. The study group consisted of 28 persons ( $\mathrm{n}=28$ ), 20 females and 8 males, with high competencies in the Polish spoken language. The feedback ratio was $40 \%$. The subjects answered three questions pertaining to the importance of cochlear implants as well as the advantages and disadvantages of their use. The obtained responses were subject to qualitative research with the use of the content analysis method. The collected data were analysed on the basis of the developed categories, thereby enabling establishment of the significance of cochlear implants as well as the benefits and drawbacks of their use reported by adults suffering from prelingual deafness.

Results: The findings were that the importance of cochlear implants was proved by their positive or very positive evaluation as well as by the improvement in the quality of life of CI users. This was most of all due to the fact that cochlear implants provide individuals with the possibility to hear, speak and communicate with others by means of spoken language. Owing to the use of CIs, some of the study subjects experienced an opportunity to self-develop or improve their social contacts with other normal-hearing people, as well as reported positive emotions connected therewith. The negative aspects of cochlear implant use included most of all operational and technical matters, e.g. the need of frequent change of batteries, difficulties resulting from the limitations in everyday activity, e.g. in sport, or connected with the medical sphere, e.g. inability to have certain medical examinations such as MRI.

Conclusions: Positive evaluation of cochlear implants by their users conformed with the findings reported in the available CI literature. Attention is drawn to the negative aspects of CI use in the perception by prelingually deaf adults, in particular to those that cause or may cause interruptions in CI operation, being the source of fear or panic sensations experienced by CI users in such situations. Various forms of psychological intervention should therefore be included in the rehabilitation offer available to CI users with prelingual deafness so as to enable them to develop effective strategies of coping with any negative experiences connected with the use of cochlear implants, as well as to confront with their own deafness.

Key words: cochlear implant $\bullet$ prelingual deafness $\bullet$ content analyses $\bullet$ advantages and disadvantages of cochlear implant

\section{Wprowadzenie}

Implant ślimakowy stał się powszechną metodą leczenia stosowaną u osób z głuchotą prelingwalną, zarówno dzieci, jak i dorosłych. W Polsce pierwsza osoba dorosła prelingwalnie ogłuchła została zaimplantowana w wieku 44 lat w 1993 roku [1], natomiast dziecko z tym rodzajem głuchoty nieco wcześniej, tj. w roku 1992 [2]. System implantu ślimakowego (fot. 1.) jest elektroniczną protezą narządu słuchu, która stymuluje elektrycznie zakończenia nerwu słuchowego w celu wzbudzenia w nim określonych potencjałów czynnościowych z pominięciem uszkodzonych komórek słuchowych, co pozwala na wykorzystanie pozaślimakowego prawidłowo funkcjonującego odcinka drogi słuchowej [3]. Składa się „z części wewnętrznej: odbiornika i stymulatora elektrycznego umieszczonych we wspólnej obudowie oraz wiązki elektrod, i części zewnętrznej cyfrowego procesora mowy" [3, s. 23].

Pomimo dużej powszechności tej metody leczenia niewiele jest badań jakościowych i ilościowych poruszających bezpośrednio problematykę znaczenia implantu ślimakowego lub (dwóch) implantów ślimakowych dla życia użytkowników, którymi są osoby dorosłe prelingwalnie głuche, z ich własnej perspektywy. Wiadomo już, że efektywność CI u tych, którzy zostali poddani wszczepieniu elektronicznej protezy słuchu jako adolescenci czy osoby dorosłe, mierzona metodami obiektywnymi, jest niższa w porównaniu $\mathrm{z}$ efektywnością implantu ślimakowego w grupie osób, które słuch utraciły w okresie postlingwalnym, tj. po opanowaniu systemu językowego [4-7]. W jednych z wcześniejszych badań $40 \%$ ich uczestników z głęboką głuchotą prelingwalną uzyskało po implantacji ślimakowej istotną poprawę w rozpoznawaniu mowy w zestawach otwartych [8]. Z drugiej strony wyniki badań pokazują, że subiektywna ocena efektywności CI, a więc percepcja korzyści lub/i satysfakcji z CI w obu grupach dorosłych użytkowników CI z głuchotą pre- lub postlingwalną, jest podobna, tj. wysoka lub bardzo wysoka [5-9]. Podobnie wysokie rezultaty dotyczą subiektywnie spostrzeganej jakości życia w tej grupie użytkowników CI, a więc z diagnozą głuchoty prelingwalnej [4-10]. W związku z powyższym autorzy prowadzonych badań w konkluzji stwierdzają, że do oceny szeroko rozumianych korzyści z CI w populacji, zwłaszcza osób prelingwalnie ogłuchłych zaopatrzonych w to urządzenie w późniejszym okresie życia, nie wystarczą rezultaty tradycyjnie dokonywanych pomiarów percepcji mowy. Należy bowiem uwzględnić również doświadczane przez nie korzyści w aspekcie jakości życia czy jakości codziennego funkcjonowania [4,6-7].

Niewielu badaczy wskazuje na fakt, że wszczepienie implantu ślimakowego dla osób dorosłych, które z niego korzystają, to nie tylko postępowanie medyczne polegające na operacyjnym zaopatrzeniu danej osoby w elektroniczne urządzenie dające możliwość słyszenia, „drugie ucho”, jak mówią niektórzy jego użytkownicy. Implantacja ślimakowa wiąże się bowiem z „wieloletnim procesem, który dotyczy całego ich świata. W tej sytuacji, to więcej niż «wyniki« $\mathrm{i}$ «poprawa percepcji (słuchowej) « mierzonej w wyznaczonych odcinkach czasowych" [10, s. 265]. Dlatego też warto wiedzieć, jak spostrzegają znaczenie CI, jego pozytywne i negatywne strony osoby dorosłe $\mathrm{z}$ głuchotą prelingwalną, zarówno te, które praktycznie wychowały się z implantem ślimakowym, co oznacza, że otrzymały go w okresie dzieciństwa [np.11], a także te, które 


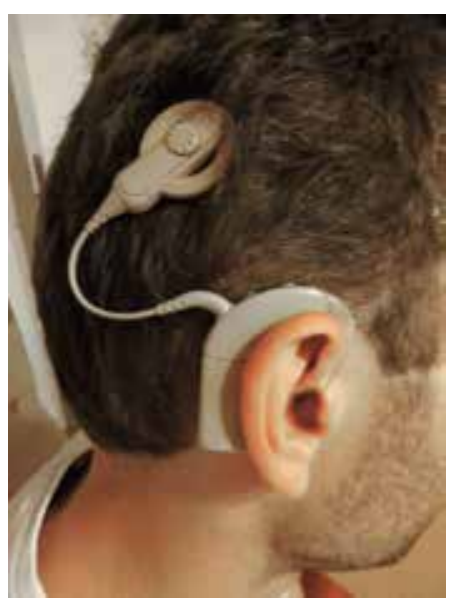

Fot. 1. Osoba dorosła z implantem ślimakowym - widoczna jest część zewnętrzna systemu implantu ślimakowego: cyfrowy procesor mowy oraz cewka zewnętrzna

Photo 1. Adult cochlear implant user - the external part of the cochlear implant is visible: a digital speech processor and an external coil

Źródło: Archiwum własne

w wieku dorastania [12] lub jako dorosłe zdecydowały się na implant ślimakowy [np. 13-14].

Podejmując zagadnienie implantu ślimakowego i jego znaczenia z perspektywy dorosłych użytkowników, którzy urodzili się głusi lub słuch utracili w okresie prelingwalnym, należy wspomnieć o istnieniu innych perspektyw spostrzegania kwestii implantów ślimakowych, a więc w szerszym niż indywidualny kontekście. W „szerszym kontekście" kształtuje się bowiem indywidualne znaczenie nadawane implantowi ślimakowemu przez jego użytkowników. W tym miejscu rozważań należy odwołać się do medycznego lub społeczno-kulturowego modelu głuchoty [15-21]. W pierwszym z nich głuchota stanowi kalectwo, wadę, deficyt, jest patologią w sensie medycznym: tj. odstępstwem od zdrowia, które należy zlikwidować, a osobie głuchej „przywrócić” słuch, by mogła funkcjonować w świecie słyszącej większości, komunikować się w języku fonicznym danego kraju i być „jak osoby słyszące”. W drugim, społeczno-kulturowym modelu głuchoty, uznaje się samą głuchotę za pozytywną wartość, a ludzi Głuchych ${ }^{1}$ za mniejszość językową (język migowy) i kulturową (kultura Głuchych). Zwolennikom tej perspektywy pojmowania głuchoty zarówno implant ślimakowy, jak i klasyczne aparaty słuchowe nie są potrzebne, wręcz przeciwnie: bywaja traktowane jako stygmatyzujace Głuchych reprezentantów tego podejścia, a sama implantacja ślimakowa jest niejednokrotnie uznawana za zagrożenie tożsamości i kultury Głuchych $[15,16,20,22]$.

Z kolei dla przedstawicieli modelu medycznego (rehabilitacyjnego) implant ślimakowy lub dwa implanty (analogicznie jak klasyczne aparaty słuchowe w minionych dekadach) stają się pewnego rodzaju „antidotum na głuchotę”, choć jej nie likwidują w sensie biologicznym. Pozwalają osobie głuchej na słyszenie i komunikowanie się z otoczeniem w różnym stopniu [2,4-14], a także sprzyjają temu, aby mogła ona, jak określa to Kazimiera Krakowiak, stać się "funkcjonalnie słyszącą" [23]. Z kolei z badań ankietowych Marty Wrześniewskiej-Pietrzak (2017) [21] wynika, że doświadczaniu głuchoty przez dorosłe osoby g/Głuche towarzyszy „poczucie tęsknoty za słyszeniem świata,

${ }^{1}$ Pisownia dużą literą G wskazuje na osoby, które posiadają ubytek słuchu w stopniu głębokim lub znacznym i reprezentują mniejszość językową (język migowy) i kulturową (kultura Głuchych). muzyki czy głosów bliskich osób” [20, s. 148], a także za rozmowami przez telefon, śpiewem ptaków czy szumem morza. Sama zaś głuchota kojarzona jest $\mathrm{z}$ cierpieniem, którego źródła tkwią w trudnościach i barierach osób głuchych doznawanych w kontekście społecznym, tworzonym przez większość, osoby słyszące [18,21,24]. Rozważając, jak jest doświadczana głuchota przez osoby g/Głuche pochodzące zazwyczaj ze słyszących rodzin, można także przywołać wyniki badań jakościowych Doroty Podgórskiej-Jachnik (2013) [18]. Jak z nich wynika, ze sposobem doświadczania głuchoty, a także siebie jako osoby głuchej, wiąże się doświadczanie swojego dzieciństwa, które we wspomnieniach dorosłych już młodych ludzi głuchych pojawia się niejednokrotnie $\mathrm{w}$ formie obrazów „chorego dzieciństwa”, ale też „pracowitego”, „samotnego”, a bywa że i „zwyczajnego" dzieciństwa.

Niezależnie od przyjmowanej perspektywy w podejściu do głuchoty: medycznej v. społeczno-kulturowej jedno jest pewne, że w obecnej dobie implanty ślimakowe „zmieniają oblicze głuchoty i społeczności g/Głuchych” [22]. Można je uznać, a raczej stosunek osób g/Głuchych do nich, jako tożsamościowy „wyróżnik”: od negatywnej percepcji CI jako zagrożenia dla społeczności g/Głuchych, języka migowego i kultury Głuchych w podejściu społeczno-kulturowym do percepcji pozytywnej, realnie dostępnego urządzenia, umożliwiającego osobie głuchej słyszenie i porozumiewanie się drogą słuchową, pełniącego funkcję „antidotum na głuchotę” w modelu medycznym. Jak mówi Judyta Zębik, jedna z pierwszych w naszym kraju osób głuchych z CI, która otrzymała implant w wieku 6 lat: „Implant jest po to, żeby słyszeć dźwięki. Ale to wcale nie znaczy, że po wszczepieniu implantu ślimakowego już staliśmy się osobami słyszącymi. Nadal jesteśmy osobami $\mathrm{z}$ wadą słuchu, tyle tylko, że używamy zupełnie innego sprzętu, który jest wciąż mało akceptowany w świecie Głuchych" [11, s. 24].

Nieliczne wciąż badania dotyczące dorosłych g/Głuchych użytkowników implantu ślimakowego (CI) pokazują, że osoby te w większości identyfikują się z kulturą słyszących i mają poczucie przynależności do osób słyszących albo do g/Głuchych i słyszących [25-31]. Jednak odwołanie się do wyników badań jakościowych pozwala stwierdzić, że osoby głuche korzystające z CI, będące w okresie dorastania, zazwyczaj nie doświadczają siebie jako zdecydowanie 
kulturowo Głuchych, ani też jako zdecydowanie kulturowo słyszących. W większości uznają one siebie za głuchych w tym sensie, że „bez CI nie słyszą” [28-29], lecz czują się "pomiędzy” głuchymi i słyszącymi, tak jak ma to miejsce w odniesieniu do dorosłych g/Głuchych z CI z innych badań [30,32].

W rozważaniach dotyczących znaczenia implantu/implantów ślimakowych dla osób prelingwalnie głuchych, które $\mathrm{z}$ niego/nich korzystają ocenianego z perspektywy ich samych nie można pominąć tego, jak doświadczają, czym jest implant ślimakowy (implanty ślimakowe), słyszący (w ok. 95\%) rodzice dzieci głuchych. W rodzinach pochodzenia dorosłych osób głuchych kształtują się podwaliny znaczenia, jakie nadają dzieci głuche, późniejsi dorośli, swojej głuchocie, a w konsekwencji implantowi ślimakowemu. Co to znaczy być głuchym, dowiadują się w relacjach z matką i ojcem poprzez emocje, jakich źródłem staje się dla nich głuchota i które to emocje wnoszone są do relacji z dzieckiem głuchym [33-35]. W badaniach jakościowo-ilościowych, którymi objęto rodziców słyszących dzieci głuchych [36], otrzymano, że implant ślimakowy jest spostrzegany w kategoriach: 1) słuchu, słyszenia (np. Umo $\dot{z}$ liwia najlepsze styszenie dla mojego dziecka) (29\% wypowiedzi rodziców ogółem), 2) nadziei i jedynej szansy (np. Szansa na normalne styszenie $i \dot{z} y c i e)$ (20\% wypowiedzi rodziców), 3) prawidłowego, normalnego, „jak u dziecka słyszącego" rozwoju (np. Dla lepszego rozwoju; Aby zrobić wszystko co możliwe, aby dziecko rozwijało się prawidłowo) (19\% wypowiedzi rodziców), 4) „braku” korzyści z klasycznych aparatów słuchowych, a także w rozwoju mowy i języka (np. W aparatach stuchowych miał mało korzyści, więc nie widziałam innego wyjścia) (17\% wypowiedzi rodziców), 5) mowy i porozumiewania się z innymi (np. W przypadku głębokiego niedosłuchu obustronnego u Piotrusia to [CI] najlepsze rozwiązanie, które pozwala mu na normalne, werbalne komunikowanie się z innymi) (15\% wypowiedzi rodziców). Należy dodać, iż matki i ojcowie nie różnili się w sposób istotny proporcją wymienianych motywów decyzji o implancie ślimakowym dla swojego głuchego dziecka. Można sądzić, że zobrazowany powyżej sposób doświadczania przez słyszących rodziców motywacji decyzji o CI będzie znajdował odzwierciedlenie w znaczeniu przypisywanym CI przez dorosłe głuche dzieci, użytkowników CI, zwłaszcza tych, którzy zostali zaopatrzeni w to urządzenie jako dzieci. Należy w tym miejscu dodać, że na świecie (stopniowo, jak można sądzić, także i w Polsce) rodzice Głusi coraz częściej decydują się na implant ślimakowy dla swojego głuchego dziecka [37], zapewniając mu w ten sposób warunki sprzyjające dwumodalnej dwujęzyczności [22], czyli dwujęzyczności migowo-fonicznej [38].

W Polsce nie ma dotychczas badań jakościowych na temat tego, jakie znaczenie ma dla dorosłych osób z głuchotą prelingwalną implant ślimakowy, a także jak - będąc jego użytkownikami - spostrzegają one pozytywne i negatywne strony tego urządzenia.

\section{Cel badań}

Prezentowane badania miały na celu poznanie, jak osoby dorosłe z głuchotą prelingwalną, które korzystają z jednego lub dwóch implantów ślimakowych (CI) od dzieciństwa, adolescencji lub dorosłości, spostrzegają to urządzenie. Chodziło o odpowiedzi na następujące pytania badawcze:

- Jakie znaczenie nadają implantowi ślimakowemu osoby dorosłe z głuchotą prelingwalną?

- Jakie są pozytywne strony implantu ślimakowego z perspektywy osób dorosłych z głuchotą prelingwalną?

- Jakie są negatywne strony implantu ślimakowego z perspektywy osób dorosłych z głuchotą prelingwalną?

Uwzględniono też wiek w momencie wszczepienia CI, satysfakcję z tego urządzenia oraz poczucie przynależności do osób głuchych, słyszących, głuchych i słyszących, a także ani do głuchych, ani do słyszących, i ich związek ze znaczeniem nadawanym CI, jak i jego pozytywnymi i negatywnymi stronami w percepcji osób dorosłych z głuchotą prelingwalną korzystających z implantu ślimakowego.

\section{Metody badań}

\section{Uczestnicy badań}

W badaniach wzięły udział osoby dorosłe z głuchotą prelingwalną, u których ubytek słuchu w lepszym uchu był większy niż $90 \mathrm{~dB}$, w wieku od 18 do 40 lat $(\mathrm{M}=26,5$; $\mathrm{SD}=7,02)$, będące użytkownikami implantu ślimakowego (lub dwóch) od dzieciństwa, adolescencji lub dorosłości, otrzymanego (pierwszy implant) średnio w wieku 14,57 lat $(\mathrm{SD}=19,13)$. Czas korzystania z CI mieścił się w przedziale od 2 do 22 lat i wynosił średnio 12,42 lat $(\mathrm{SD}=4,75)$. Uczestników badań dobrano, uwzględniając ich (wysokie) kompetencje językowe w języku polskim fonicznym, zgodnie $z$ oceną dokonywaną przez surdologopedów i surdopedagogów dobrze znających te osoby. Badania przeprowadzono metodą korespondencyjną; a pakiety $\mathrm{z}$ ankietami wysłane zostały do 67 osób, z czego otrzymano 28 wypełnionych, co stanowi wskaźnik odpowiedzi zwrotnych równy $40 \%$.

Grupa biorących udział w badaniach składała się z 20 kobiet i 8 mężczyzn. W związku partnerskim lub małżeńskim pozostawało 9 osób, co stanowi $32,1 \%$. Osoby $\mathrm{z}$ wykształceniem wyższym lub te, które były w trakcie studiowania, stanowiły $57,1 \%$. Zatrudnionych było 14 osób $(46,1 \%)$, bez pracy pozostawały 3 osoby. Tylko jedna osoba miała rodziców głuchych, pozostałe słyszących. Deklarowana znajomość języka migowego przedstawiała się następująco: bardzo dobra i dobra $(\mathrm{n}=8)$, trochę znam $(n=6)$, słaba $(n=5)$, brak znajomości języka migowego $(n=9)$.

Satysfakcja $\mathrm{z}$ implantu ślimakowego mierzona na skali VAS wynosiła w przeliczeniu na procenty średnio $M=81,49$; $\mathrm{SD}=18,46$ i mieściła się $\mathrm{w}$ przedziale od 29,19 do 99,38\%. Wśród osób badanych implant ślimakowy do 12 roku życia otrzymało $13(46,4 \%)$ osób, a powyżej tego wieku $15(53,6 \%)$ osób. Poczucie przynależności do osób słyszących zadeklarowało 15 (53,6\%) uczestników badań, do słyszących i głuchych 12 (42,8\%), natomiast na swoją przynależność ani do słyszących, ani do głuchych wskazała 1 osoba. Nikt $\mathrm{z}$ badanych nie określił swej przynależności jako wyłącznie do osób głuchych. Charakterystyka uczestników badań z uwzględnieniem płci, wieku, wieku w momencie otrzymania CI, satysfakcji z CI oraz 
Kobosko J. i wsp.: Implant ślimakowy z perspektywy osób...

\begin{tabular}{|c|c|c|c|c|c|}
\hline KOD & PŁEĆ & WIEK & $\begin{array}{l}\text { WIEK W MOMENCIE } \\
\text { WSZCZEPIENIA CI }\end{array}$ & $\begin{array}{l}\text { POCZUCIE PRZYNALEŻNOŚCI } \\
\text { styszący, głusi, słyszący i głusi, } \\
\text { ani styszący, ani głusi }\end{array}$ & $\begin{array}{c}\text { SATYSFAKCJA Z Cl } \\
{[\%]}\end{array}$ \\
\hline A1 & kobieta & 37 lat & 24 lata & słyszący i głusi & 52,17 \\
\hline $\mathrm{A} 2$ & kobieta & 26 lat & 14 lat & słyszący & 46,58 \\
\hline A3 & kobieta & 18 lat & 11 lat & styszący & 66,4 \\
\hline A4 & mężczyzna & 26 lat & 5 lat & słyszący i głusi & 97,51 \\
\hline A5 & mężczyzna & 25 lat & 17 lat & styszący & 95,03 \\
\hline A6 & kobieta & 37 lat & 26 lat & styszący & 67,7 \\
\hline A7 & mężczyzna & 29 lat & 19 lat & słyszący i głusi & 49,68 \\
\hline A8 & mężczyzna & 36 lat & 18 lat & słyszący & 77,63 \\
\hline A9 & kobieta & 40 lat & 30 lat & styszący i głusi & 76,39 \\
\hline A10 & kobieta & 27 lat & 5 lat & styszący & 29,19 \\
\hline A11 & kobieta & 40 lat & 33 lata & styszący & 97,51 \\
\hline A12 & kobieta & 20 lat & 12 lat & styszący & 85,71 \\
\hline A13 & kobieta & 20 lat & 3,5 roku & słyszący & 91,3 \\
\hline A14 & kobieta & 19 lat & 4 lata & słyszący i głusi & 97,51 \\
\hline A15 & kobieta & 19 lat & $\begin{array}{c}\text { Pierwszy } \mathrm{Cl}-13 \text { lat } \\
\text { Drugi } \mathrm{Cl}-14 \text { lat }\end{array}$ & słyszący & 98,13 \\
\hline A16 & kobieta & 39 lat & 29 lat & słyszący & 99,37 \\
\hline A17 & mężczyzna & 18 lat & 1 rok & styszący & 86,95 \\
\hline A18 & kobieta & 31 lat & 24 lata & styszący & 97,51 \\
\hline A19 & kobieta & 25 lat & 13 lat & styszący & 97,51 \\
\hline $\mathrm{A} 20$ & kobieta & 25 lat & 13 lat & słyszący i głusi & 81,96 \\
\hline $\mathrm{A} 21$ & kobieta & 23 lata & 21 lat & słyszący i głusi & 81,96 \\
\hline $\mathrm{A} 22$ & kobieta & 24 lata & 5 lat & słyszący i głusi & 97,51 \\
\hline A23 & kobieta & 24 lata & 8 lat & ani słyszący, ani głusi & 90,68 \\
\hline $\mathrm{A} 24$ & mężczyzna & 18 lat & 2 lata & słyszący i głusi & 99,37 \\
\hline $\mathrm{A} 25$ & kobieta & 21 lat & 4 lata & słyszący i głusi & 83,85 \\
\hline $\mathrm{A} 26$ & mężczyzna & 28 lat & 17 lat & słyszący & 82,6 \\
\hline $\mathrm{A} 27$ & kobieta & 24 lata & 6 lat & słyszący i głusi & 77.63 \\
\hline A28 & mężczyzna & 26 lat & 16 lat & słyszący & 76,39 \\
\hline
\end{tabular}

Tabela. 1. Charakterystyka uczestników badań - użytkowników implantu ślimakowego $(\mathrm{Cl})$ z głuchotą prelingwalną $(\mathrm{n}=28)$ oraz kody przypisane każdej z osób: od A1 do A28

Table 1. Characteristics of study participants - prelingually deaf cochlear implant $(\mathrm{Cl})$ users $(n=28)$ and their assigned codes: $A 1$ to A28

poczucia przynależności do osób słyszących, głuchych i słyszących, głuchych, ani głuchych, ani słyszących zawarta została w tabeli 1 .

\section{Narzędzia badawcze i metoda analizy danych}

Ankieta informacyjna - zawierała pytania dotyczące zmiennych socjodemograficznych, zmiennych związanych z głuchotą i implantem ślimakowym osób badanych. Zawarto w niej stwierdzenie służące ocenie satysfakcji z CI.

Satysfakcja z implantu ślimakowego - osoba badana zaznaczała na skali wizualno-analogowej (VAS), której krańce były oznaczone od 1 do 10 , na ile jest zadowolona $\mathrm{z}$ implantu ślimakowego. Linia ta miała długość $161 \mathrm{~mm}$, a pomiaru zadowolenia z CI dokonywano w milimetrach, następnie przeliczano na skalę procentową.
Implant ślimakowy $w$ wypowiedziach ankietowych. W Ankiecie znalazły się trzy pytania otwarte związane z implantem ślimakowym: 1) „Jakie znaczenie ma dla Ciebie implant ślimakowy?", 2) „Jakie są Twoim zdaniem pozytywne strony implantu ślimakowego?", 3) „Jakie są Twoim zdaniem negatywne strony implantu ślimakowego?”. Osoba badana miała ograniczoną do kilku linijek przestrzeń na swoją wypowiedź. Zebrane swobodne wypowiedzi ankietowe zostały poddane analizie jakościowej z zastosowaniem metody, jaką jest analiza treści (ang. Content Analysis) [39]. Jednostką analizy jest „jednostka znaczeniowa” (ang. meaning unit), tj. słowo, zdanie, równoważnik zdania i in., którą to można przypisać do danej kategorii. Kategorie do analizy treści (inaczej obszary, w których ankietowani lokują swoje zalety i wady CI) zostały zaproponowane po zapoznaniu się autorek (JK, AP, AGS) ze wszystkimi wypowiedziami respondentów, a więc określić je można 
mianem kategorii eksploracyjnych. W jednej wypowiedzi osoby badanej mogła być jedna lub kilka „jednostek znaczeniowych". Wypowiedź na pytanie 1. z Ankiety, np. Ułatwia funkcjonowanie w środowisku osób słyszących, stanowi jedną ,jednostkę znaczeniową" (kategoria: „Relacje społeczne i funkcjonowanie w świecie ludzi słyszących v. głuchych"), natomiast wypowiedź, np. Dzięki implantowi moge styszeć i porozumiewać się $z$ rodzina i innymi osobami w moim otoczeniu. Dzięki temu, że słyszę, też mówię, zawiera dwie ,jednostki znaczeniowe” - jedną związaną ze słyszeniem (kategoria: „Słyszenie a implant ślimakowy”), drugą związaną z mową i porozumiewaniem się (kategoria: „Mowa i porozumiewanie się a implant ślimakowy"). W celu analizy treści zebranych wypowiedzi ankietowych wyodrębniono następujące kategorie, nieco odmienne względem każdej grupy wypowiedzi (na trzy zadane w Ankiecie pytania):

Znaczenie implantu ślimakowego (wypowiedzi ankietowe na pytanie 1) - zaproponowane kategorie analizy treści:

- Waloryzacja pozytywna implantu ślimakowego (np. Implant ślimakowy ma dla mnie duże znaczenie).

- Jakość życia a implant ślimakowy (np. Implant całkowicie zmienił moje życie, bardzo je ułatwit w wielu aspektach).

- Słyszenie a implant ślimakowy (np. Dzięki implantowi moge styszeć).

- Mowa i komunikowanie się a implant ślimakowy (np. Pozwala mi na swobodna bez przeszkód rozmowe).

- Sfera Ja a implant ślimakowy (np. Daje pewność siebie. Pozbyłam się kompleksu niższości z powodu niedosłuchu).

- Emocje a implant ślimakowy (np. Nie boje się próbować nowych rzeczy).

- Relacje społeczne i funkcjonowanie w świecie ludzi słyszących v. głuchych a implant ślimakowy (np. Ułatwia funkcjonowanie w środowisku osób styszących).

- Rehabilitacja a implant ślimakowy, (czasem) odniesienie do aparatów słuchowych lub decyzji o CI (np. To dzięki niemu moja rehabilitacja dała duże efekty).

- Praca a implant ślimakowy (np. Dzięki implantacji znalazłam lepsza pracę).

- Edukacja a implant ślimakowy (np. Dzięki implantacji i pomocy innych osób ukończyłam studia).

Pozytywne strony implantu ślimakowego (wypowiedzi ankietowe na pytanie 2) - zaproponowane kategorie analizy treści:

- Słyszenie a implant ślimakowy (np. Szeroki wachlarz dźwięków, możliwość poznawania kolejnych ciekawych dźwięków).

- Mowa i komunikowanie się a implant ślimakowy (np. Ułatwia mi rozumienie ze słuchu, do tej pory czytałam tylko i wyłacznie $z$ ust).

- Muzyka a implant ślimakowy (np. Moge stuchać lepiej muzykę poprzez specjalny kabel).

- Relacje społeczne i funkcjonowanie w świecie ludzi słyszących v. głuchych a implant ślimakowy (np. Zmniejszenie poczucia wykluczenia od „styszącej większości” społeczeństwa).

- Sfera Ja a implant ślimakowy (np. Mocno poprawia moje nie tylko zdrowie, ale też samopoczucie).

- Edukacja a implant ślimakowy - zmniejszenie ograniczeń (np. Możliwość uczestniczenia w normalnych lekcjach nawet $z$ nauczycielem czasem się odwracajacym).
- Implant ślimakowy jako urządzenie techniczne (np. Wyłacza się go na noc - cicha noc).

- Rehabilitacja a implant ślimakowy (np. Moja rehabilitacja poszła bardzo do przodu).

- Waloryzacja pozytywna implantu ślimakowego (np. Najlepsza technologia medyczna).

Negatywne strony implantu ślimakowego (wypowiedzi ankietowe na pytanie 3) - zaproponowane kategorie analizy treści:

- Ograniczenia „techniczno-eksploatacyjne” a implant ślimakowy (np. Częsta zmiana baterii; Brak wodoodporności (a przynajmniej na pot), Podatny na uszkodzenia mechaniczne).

- Ograniczenia medyczne a implant ślimakowy (np. Niemożność wykonania rezonansu magnetycznego).

- Ograniczenia „słuchowe” a implant ślimakowy (np. Nie jest to $100 \%$ slyszenia, ale i tak bardzo dużo!).

- Ograniczenia estetyczne a implant ślimakowy (np. Procesor mógłby być mniejszy albo ulokowany tylko pod skórq).

- Ograniczenie aktywności a implant ślimakowy (np. Często część implantu na uchu spada, szczególnie przy gwattownych ruchach $i$ ćwiczeniu).

- Koszty a implant ślimakowy (np. Wysokie koszty eksploatacji, głównie koszty baterii).

- Ograniczenia psychologiczne a implant ślimakowy (np. Uprzedzenia osób nieznających takich jak ja (widać „coś” na głowie)).

- Ograniczenia „rehabilitacyjne” a implant ślimakowy (np. Ciagła rehabilitacja).

- Brak negatywnych stron implantu ślimakowego (np. Nie widze negatywnych stron).

\section{Wyniki}

\section{Znaczenie implantu ślimakowego dla osób dorosłych z głuchotą prelingwalną - analiza treści wypowiedzi ankietowych}

Wypowiedzi ankietowe na pytanie o znaczenie implantu ślimakowego (CI) otrzymano od 26 osób spośród 28 uczestniczących w badaniach (jedna nie udzieliła odpowiedzi [A2] ${ }^{2}$, druga napisała: „nie wiem” [A7]). Wyróżniono 10 kategorii analizy ich treści po uprzednim wyodrębnieniu ,jednostek znaczeniowych" w całym materiale, których uzyskano w odpowiedzi na to pytanie ogółem 67 , co oznacza, że na jedną osobę przypada średnio od 2 do 3 wypowiedzi z różnych kategorii (dla całej grupy uczestników ich rozkład wg ustalonych kategorii przedstawiono na wykresie - rycina 1 ).

W wyniku analizy treści wypowiedzi ankietowych na pytanie 1 wyróżnione zostały dwie kategorie ogólne: „Waloryzacja pozytywna implantu ślimakowego" oraz "Jakość życia” w aspekcie jej poprawy w związku z CI, a także 7 kategorii szczegółowych: „Słyszenie”, „Mowa

\footnotetext{
${ }^{2} \mathrm{~W}$ analizie wyników odwołano się do wybranych wypowiedzi osób badanych, którym przypisano kody (litera A plus numer) podawane przy cytowaniu ich wypowiedzi w tekście. Charakterystyka uczestników badań (płeć, wiek, wiek w momencie wszczepienia CI, poczucie przynależności do słyszących v. głuchych oraz satysfakcja z CI) zgodnie z przypisanymi kodami znajduje się w tabeli 1.
} 


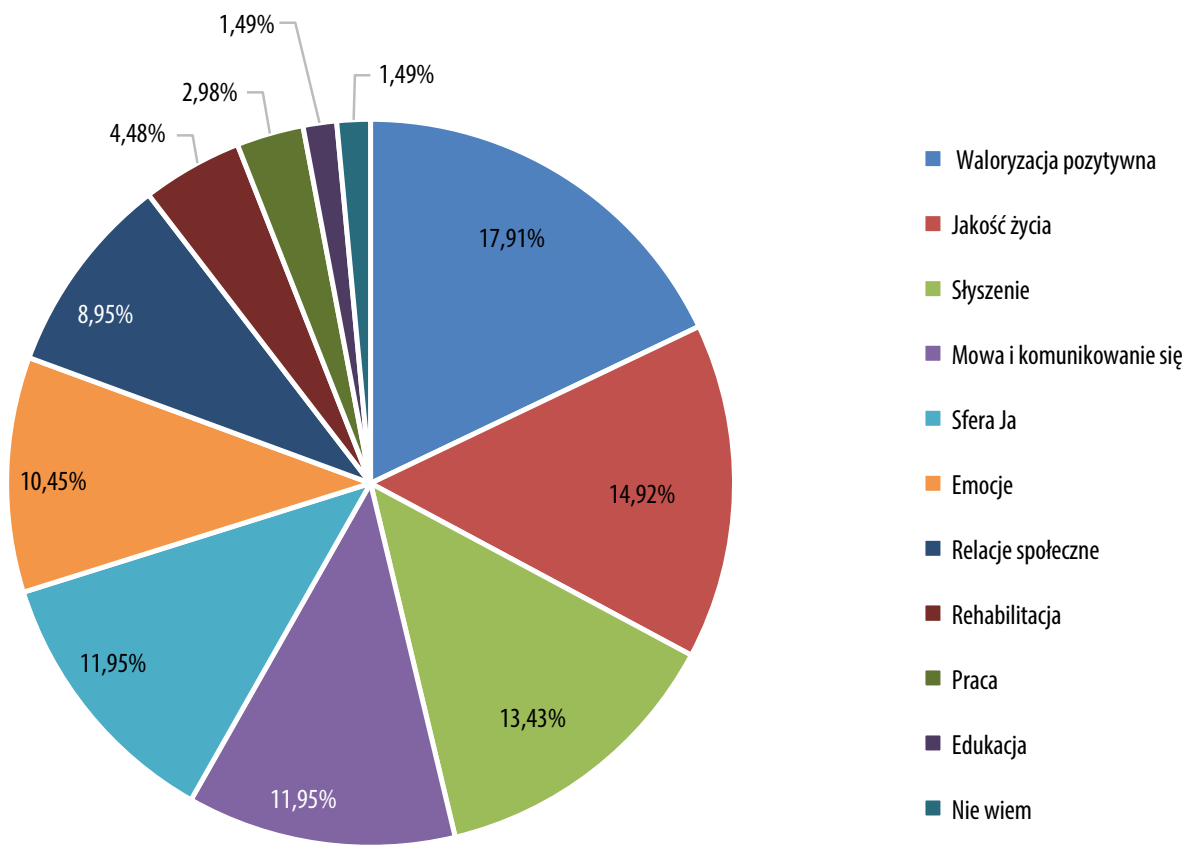

Rycina 1. Znaczenie implantu ślimakowego (CI) w wypowiedziach ankietowych osób dorosłych z głuchotą prelingwalną - rozkład wypowiedzi (,jednostek znaczeniowych" - $n=67$ ) według wyodrębnionych w analizie treści kategorii.

Figure 1. Significance of cochlear implant $(\mathrm{Cl})$ in questionnaire for adults with prelingual deafness - distribution of utterances ("meaning units" $-n=67$ ) according to separate categories based on the content analysis.

i komunikowanie się”, „Emocje” związane z CI, „Sfera Ja” i zmiany doświadczane w poczuciu badanych jako wynik korzystania z CI, „Relacje społeczne i funkcjonowanie w świecie ludzi słyszących v. głuchych”, „Rehabilitacja”, „Praca” oraz „Edukacja”.

Waloryzacja pozytywna implantu ślimakowego. Osoby prelingwalnie głuche z CI dość często w odpowiedzi na zadane w Ankiecie pytanie o znaczenie CI określały je jako „ogromne, wielkie, duże..."; a oceny z tej kategorii dokonało 12 spośród 28 osób $(46,15 \%)$ uczestniczących w badaniach, niezależnie od tego, kiedy został im wszczepiony. Poniżej podano przykłady wypowiedzi ankietowych $\mathrm{z}$ omawianej kategorii:

- „Jest bardzo ważny, mam go od dziecka”. [A17]

- „Implant ślimakowy to najcudowniejszy wynalazek na świecie”. [A10]

- „Tak więc implant i procesor to moje ucho jedyne”. [A16]

- „Ogromne. Nie jestem w stanie tego wymienić”. [A11]

Jakość życia a implant ślimakowy. Kolejną często wymienianą kategorią ogólną, pojawiającą się w odpowiedzi na pytanie o znaczenie CI, jest jakość życia w różnych aspektach, od niemożności funkcjonowania bez CI do komfortu w związku z jego użytkowaniem. Znaczenie przynależne tej kategorii nadane zostało implantowi ślimakowemu przez 10 osób $(38,46 \%)$ :

- „Nie potrafię żyć bez implantu”. [A10]

- „Ogólnie po implantacji poprawiła mi się jakość mojego życia”. [A6]
- „Nie potrafię bez niego funkcjonować w życiu, mimo tego że wcześniej używałam aparat słuchowy, z którego niewiele korzystałam". [A11]

Słyszenie a implant ślimakowy. Do „słuchu i możliwości słyszenia" dzięki korzystaniu z CI odwołało się 9 osób (34,61\%) spośród biorących udział w badaniach. Przykłady wypowiedzi wchodzących w skład tej kategorii:

- „Dzięki implantowi mogę słyszeć”. [A22]

- „Dzięki temu słyszę dźwięki otoczenia, np. ostrzeżenia”. [A27]

- „Po prostu dużo lepiej słyszę”. [A28]

Mowa i komunikowanie się a implant ślimakowy. $\mathrm{Na}$ korzyści w obszarze rozumienia mowy i komunikowania się z innymi jako mające znaczenie w związku z CI wskazało 8 osób (28,57\%) spośród badanych. Przykłady wypowiedzi z tej kategorii:

- „Dzięki implantowi mogę słyszeć i porozumiewać się $z$ rodziną i innymi osobami w moim otoczeniu. Dzięki temu, że słyszę, też mówię". [A22]

- „Rozmowa przez telefon, nauka języków obcych”. [A28]

- „Jest lepsze rozumienie mowy, mimo że nadal wspomagam się odczytywaniem z ruchu warg”. [A6]

Sfera Ja a implant ślimakowy. Niektórzy użytkownicy CI z głuchotą prelingwalną, a było to 8 osób $(28,57 \%)$, wypowiadając się w Ankiecie o jego znaczeniu, odnosili się do kategorii, którą określono jako „sfera Ja”. Kilku ankietowanych postrzegało implant ślimakowy jako źródło pewności 
siebie i bezpieczeństwa, inni widzieli w tym urządzeniu motywację do rozwoju, jeszcze inni spostrzegali CI w kategoriach umożliwienia samodzielności. Przykłady wypowiedzi podane zostały poniżej:

- „Jestem spokojna i pewna siebie”. [A19]

- „Bez niego bym nie była w miejscu takim, jakim jestem". [A15]

- „Pozwala mi na swobodne poruszanie, niezależność w załatwianiu spraw”. [A23]

Emocje a implant ślimakowy. W wypowiedziach 7 osób (25\%), co stanowi 10,45\% ,jednostek znaczeniowych" ogółem, w odpowiedzi na pytanie o znaczenie CI (rycina 1) pojawiły się emocje i stany emocjonalne doświadczane przez uczestników badań w związku z implantem ślimakowym. Są one w większości pozytywne, jak szczęście, zadowolenie, radość, ale czasem wyrażone zostają emocje negatywne, jak lęk czy żal, co zostało uwidocznione w poniższych przykładach:

- „Cieszę się, że mogę nosić implant”. [A13]

- „Mam wielkie szczęście, że noszę implant”. [A4]

- „Nie boję się próbować nowych rzeczy”. [A1]

Należy w tym miejscu zwrócić uwagę, że emocje negatywne, jeśli się pojawiają $\mathrm{w}$ wypowiedziach ankietowych, to są one wyrażone zazwyczaj w formie negacji. Aby dotrzeć do emocji „zanegowanych”, jak np. lęk („Nie boję się...” [A1]), należałoby przeprowadzić $\mathrm{z}$ tymi uczestnikami badań pogłębione wywiady psychologiczne.

Relacje społeczne i funkcjonowanie w świecie ludzi słyszących v. głuchych a implant ślimakowy. Pośród wypowiedzi uczestników badań znalazły się takie, w których autorzy (6 osób - 21,42\%) odwoływali się do relacji społecznych ogółem, a także relacji społecznych z osobami słyszącymi, posługując się opozycją głuchota - słyszenie. Niekiedy nawiązują one też do problemu tożsamości jako osoby głuchej, chociaż autorzy nie podejmują w sposób otwarty tego zagadnienia. Przykłady wypowiedzi z tej kategorii:

- „Bez implantu nie byłbym w stanie funkcjonować w świecie osób słyszących”. [A8]

- „Dzięki implantowi ślimakowemu jestem w stanie prowadzić normalne życie jak inne osoby słyszące”. [A26]

- „Że mogę słyszeć jak osoba słysząca”. [A5]

- „Na początku nie wpływało na poprawne relacje z rówieśnikami, dopiero na studiach po 6 latach korzystania $\mathrm{z}$ implantu, wpływało na lepsze relacje $\mathrm{z}$ ludźmi”. [A19]

Rehabilitacja a implant ślimakowy. Niektóre osoby (3 osoby - 10,71\%) nawiązywały do zagadnień rehabilitacji w aspekcie jej efektywności po wszczepieniu CI czy też $\mathrm{w}$ porównaniu $\mathrm{z}$ klasycznymi aparatami słuchowymi. Jedna z uczestniczek odniosła się do decyzji jej rodziców o CI. Przykłady wypowiedzi podano poniżej:

- „Wcześniej używałam aparat słuchowy, z którego niewiele korzystałam”. [A11]

- „Implant pozwolił mi lepiej przeprowadzić rehabilitację". [A19]
- „To dzięki niemu moja rehabilitacja dała duże efekty”. [A21]

Praca a implant ślimakowy. Problematykę pracy poruszyły 2 osoby $(7,14 \%)$, wskazując na większe możliwości $\mathrm{w}$ tej sferze związane $\mathrm{z}$ korzystaniem $\mathrm{z}$ CI:

- „Dzięki implantacji znalazłam lepszą pracę”. [A6]

- „Ułatwia funkcjonowanie w środowisku osób słyszących, aktywność zawodowa”. [A27]

Edukacja a implant ślimakowy. Z edukacją wiąże znaczenie CI tylko 1 osoba $(3,57 \%)$, co pokazuje w swojej wypowiedzi:

- „Dzięki implantacji i pomocy innych osób ukończyłam studia”. [A6]

\section{Pozytywne strony implantu ślimakowego $z$ perspektywy osób dorosłych $z$ głuchotą prelingwalną - analiza treści wypowiedzi ankietowych}

Korzyści z implantu ślimakowego wskazało 26 osób ankietowanych, a razem stanowią one 56 wypowiedzi (,jednostek znaczeniowych"); jedna osoba nie odpowiedziała na pytanie [A2], jedna napisała „nie wiem” [A7]. Wyodrębniono następujące kategorie analizy treści otrzymanych wypowiedzi ankietowych: „Słyszenie”, „Mowa i komunikowanie się”, „Relacje społeczne i funkcjonowanie w świecie ludzi słyszących v. głuchych”, „Muzyka”, „Sfera Ja”, „Rehabilitacja”, „Edukacja”, „Eksploatacja CI”, „Waloryzacja pozytywna" (dla całej grupy uczestników rozkład wypowiedzi wg kategorii przedstawiono na wykresie - rycina 2).

Słyszenie a implant ślimakowy. Wypowiedzi z tej kategorii zdecydowanie dominują i stanowią 35,72\% wszystkich „jednostek znaczeniowych” ogółem. Ankietowani akcentują w nich nie tylko sam fakt słyszenia w CI, lecz także słyszenie (coraz) większej gamy dźwięków, a także słyszenie $\mathrm{w}$ trudnych akustycznie warunkach, do jakich należy hałas w tle czy odbiór dźwięków, które znajdowały się „poza zasięgiem” usłyszenia ich w aparatach słuchowych. Poniżej cytowane wypowiedzi obrazują tę grupę korzyści doświadczanych przez osoby prelingwalnie głuche z CI:

- „Słyszenie, słyszenie”. [A10]

- „Możliwość usłyszenia szerszej gamy dźwięków”. [A3]

- „Szeroki wachlarz dźwięków, możliwość poznawania kolejnych ciekawych dźwięków”. [A5]

- „Usłyszenie wszystkich spółgłosek i odróżnianie wszystkich spółgłosek, wyraziste brzmienia w przeciwieństwie do aparatu słuchowego". [A1]

- „Słyszy się wszystkie dźwięki (np. w aparatach nie słyszałam ptaków)”. [A15]

- „Mniej czytanie z ruchu warg, dużo odbioru słuchowego". [A14]

- „Odróżnianie dźwięków z tła hałasu”. [A1]

- „Mogę usłyszeć szum morza”. [A13]

Mowa i komunikowanie się a implant ślimakowy. Drugą co do liczby wypowiedzi (,jednostek znaczeniowych”) grupę korzyści z CI stanowi obszar związany z (lepszym) rozumieniem mowy i komunikowaniem się $\mathrm{z}$ otoczeniem 


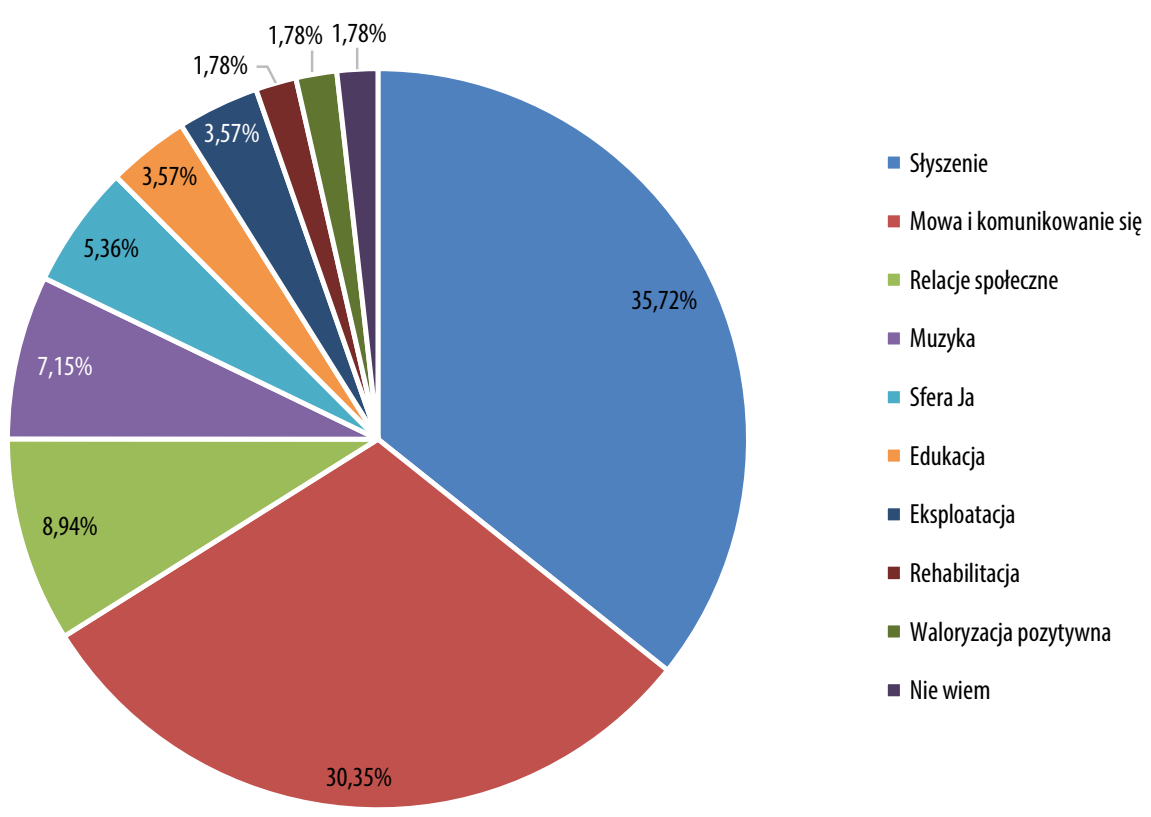

Rycina 2. Pozytywne strony implantu ślimakowego $(\mathrm{Cl})$ w wypowiedziach ankietowych osób dorosłych z głuchotą prelingwalną - rozkład wypowiedzi (,jednostek znaczeniowych" - $\mathrm{n}=56$ ) według wyodrębnionych w analizie treści kategorii

Figure 2. Advantages of the cochlear implant $(\mathrm{Cl})$ in questionnaire for adults with prelingual deafness - distribution of utterances ("meaning units" $-\mathrm{n}=56$ ) according to separate categories based on the content analysis

(30,35\%). Niektórzy dostrzegają ogólnie „lepsze rozumienie mowy" [A6], inni wskazują aspekt komunikacyjny związany $\mathrm{z}$ rozumieniem mowy czy warunki rozumienia mowy, jak np. „rozumienie ze słuchu” czy podczas rozmowy przez telefon lub w grupie. Ci, którzy wcześniej korzystali z aparatów słuchowych, dokonują porównania na korzyść CI, odnosząc się do ogólnie lepszych efektów w omawianej sferze. Ilustrują to wybrane przykłady wypowiedzi:

- „Niektóre samogłoski „łapię”, czasem łapię słowa, zdania zależnie od dykcji mówiącej osoby i w cichym otoczeniu oraz z bliska”. [A1]

- „Lepiej komunikuję się z ludźmi”. [A21]

- „Dobrze rozumiem mowę w ciszy (bez czytania z ust)”. [A27]

- „Mogę rozmawiać przez telefon z rodziną”. [27]

- „Możemy normalnie rozmawiać z osobami słyszącymi”. [A25]

- „Słyszę, mówię, rozumiem”. [A22]

Relacje społeczne i funkcjonowanie w świecie ludzi słyszących v. głuchych a implant ślimakowy. Niektórzy myśląc o korzyściach związanych z CI, wymieniają różne strony społecznego funkcjonowania $(8,94 \%$,jednostek znaczeniowych” ogółem), a więc poznanie „takich samych” osób z podobnym problemem i implantem ślimakowym czy „niezwykłych ludzi”, jak to określił jeden z biorących udział w badaniach [A17]. W innych wypowiedziach ważne okazuje się zmniejszenie poczucia wykluczenia ze „słyszącej większości” społeczeństwa czy łatwiejsze funkcjonowanie wśród słyszących dzięki korzyściom z CI.

- „Poznanie nowych osób z podobnym problemem i również implantowanych". [A14]
- „Wydaje mi się, że zdecydowanie łatwiej mi przychodzi funkcjonowanie wśród słyszących niż to było w przypadku aparatów słuchowych". [A16]

- „Zmniejszenie poczucia wykluczenia od „słyszącej większości" społeczeństwa”. [A26]

Muzyka a implant ślimakowy. Wśród osób badanych kilka z nich zwróciło uwagę w swoich wypowiedziach $(7,15 \%$ „jednostek znaczeniowych” ogółem) na możliwość odbioru muzyki, co ma miejsce w związku z korzystaniem z CI. Niektórzy określają tę możliwość jako „słuchanie” muzyki, inni jako „rozumienie” muzyki, co pokazują poniższe wypowiedzi:

- „Możliwość słuchania muzyki”. [A6]

- „Rozumienie muzyki”. [A19]

- „Mogę słuchać lepiej muzykę poprzez specjalny kabel”. [A28]

Sfera Ja a implant ślimakowy. W kilku wypowiedziach związanych z pozytywnymi stronami CI odwołano się do „sfery Ja” (5,36\% „jednostek znaczeniowych” ogółem), tj. lepszego samopoczucia, zwiększonej samoświadomości czy bezpieczeństwa. Chociaż nie wiadomo, jakie bezpieczeństwo autor miał na myśli, postawiono hipotezę, że chodzi w tej wypowiedzi także o „poczucie bezpieczeństwa”, a więc kategorię psychologiczną, nie zaś wyłącznie o bezpieczeństwo czysto fizyczne. Ponadto jest to jedyna wypowiedź nawiązująca do kwestii bezpieczeństwa, niezależnie od tego, o jakie bezpieczeństwo chodzi.

- „Mocno poprawia moje nie tylko zdrowie, ale też samopoczucie”. [A4]

- „Większa samoświadomość”. [A17] 
- „Bezpieczeństwo”. [A8]

Edukacja a implant ślimakowy. Za korzyści płynące z użytkowania CI związane z kształceniem (3,57\% „jednostek znaczeniowych” ogółem) uznano możliwość uczestniczenia w „normalnych” lekcjach, nawet gdy czasem twarz nauczycieli jest niedostępna obserwacji, a tym samym wspieranie się odczytywaniem mowy z ust jest utrudnione lub całkowicie uniemożliwione. Wskazano także na możliwość lepszego opanowania języka obcego, o czym mówią poniższe wypowiedzi:

- „Możliwość uczestniczenia w normalnych lekcjach nawet z nauczycielem czasem się odwracającym”. [A14]

- „Lepsze opanowanie języka angielskiego”. [A19]

Eksploatacja implantu ślimakowego. Dwie osoby (3,57\% „jednostek znaczeniowych” ogółem) uznały za dobrą stronę CI możliwość jego wyłączenia, kiedy jest to potrzebne lub konieczne, np. podczas snu:

• „Wyłącza się go na noc - cicha noc”. [A15]

Rehabilitacja a implant ślimakowy. W kategoriach postępu w rehabilitacji słuchu i mowy wyraziła się jedna osoba (1,78\% ,jednostek znaczeniowych” ogółem), uznając go za pozytywną stronę implantacji:

- „Moja rehabilitacja poszła bardzo do przodu”. [A21]

Waloryzacja pozytywna implantu ślimakowego. Ocena CI jako „najlepszej technologii medycznej” znalazła się w wypowiedzi jednej osoby $(1,78 \%$,jednostek znaczeniowych" ogółem) wypowiadającej się w ten sposób:

- „Najlepsza technologia medyczna”. [A4]

\section{Negatywne strony implantu ślimakowego $z$ perspektywy osób dorosłych $z$ głuchotą prelingwalną - analiza treści wypowiedzi ankietowych}

Po analizie wypowiedzi ankietowych na pytanie dotyczące negatywnych stron implantu ślimakowego okazało się, że jedna osoba nie udzieliła odpowiedzi [A2], dwie wyraziły opinię, że ich nie widzą [A18, A25]. Ogółem wyodrębnione ,jednostki znaczeniowe" w liczbie 65 uporządkowano w 9 kategorii wskazujących na różne ograniczenia związane z korzystaniem z CI: "techniczno-eksploatacyjne”, „ograniczenia aktywności”, „koszty”, „ograniczenia medyczne”, „słuchowe”, „estetyczne”, „psychologiczne”, „rehabilitacyjne”, „ograniczenia w rozumieniu mowy i komunikowaniu się". Wyróżniona została też kategoria „brak negatywnych stron CI” w percepcji osób badanych (dla całej grupy uczestników rozkład wypowiedzi wg kategorii przedstawiono na wykresie - rycina 3 ).

Ograniczenia „techniczno-eksploatacyjne” a implant ślimakowy. W tej grupie wypowiedzi znalazło się 26 ,jednostek znaczeniowych”, co stanowi $40 \%$ otrzymanych ogółem w odpowiedzi na pytanie 3, z czego prawie połowa (10) dotyczy baterii, ich „częstej zmiany, szybkiego zużywania się". Następnie pojawiają się czasem pojedyncze głosy o tym, że wadą CI jest ciągła dbałość o to urządzenie, a także brak wodoodporności, wymiany kabelka, „wypadanie" procesora zza ucha, podatność na uszkodzenia mechaniczne czy sprzężenia zwrotne. Poniżej zacytowano wybrane wypowiedzi:

- „Szybkie zużywanie baterii”. [A5]

- „Baterie szybko się rozładowują”. [A24]

- „Brak informacji o obecnym stanie baterii, tj. ile zostało do rozładowania”. [A3]

- „Drogie baterie do procesora mowy”. [A6]

- „Brak słuchu w < mokrym > środowisku”. [A17]

- "Częste wyładowania elektrostatyczne”. [A6]

- „Konieczność nieuchronnej ochrony sprzętu przed wodą, urażeniem itp... [A17]

- „Niepewność co do wymiany procesora”. [A9]

- „Obsługa pilota jest zbędna. Lepiej by były przyciski na obudowie procesora". [A28]

Ograniczenia aktywności a implant ślimakowy. Drugą co do wielkości grupą wśród negatywnych stron użytkowania CI (9 „jednostek znaczeniowych” - 13,84\%) są w percepcji ankietowanych wszelkie ograniczenia w podejmowanej aktywności, jakich doświadczają, od sytuacji określonej jako „delikatna głowa” [A21] po niewygody doznawane w pozycji leżącej, podczas gwałtownych ruchów, uprawiania sportu do obaw o jego zepsucie w różnych codziennych interakcjach. Niektórzy wskazują, że „uzależnienie od implantu” [A8] jest jego negatywną stroną, a także „brak możliwości natychmiastowej (czy w ogóle) wymiany części (np. z powodów finansowych)" [A16]. Poniżej znajdują się przykłady jeszcze innych wypowiedzi z tej kategorii:

- „Konieczność troski o cenny przedmiot (sport)”. [A17]

- "Zdarzają się sytuacje, gdy implant się odczepia lub na przykład nie pozwala położyć się wygodnie na łóżku”. [A26]

- „Czasem ogarnia mnie strach, co będzie, jeśli procesor (lub implant) się uszkodzi.... [A16]

- „Nagłe wyczerpanie baterii wyłącza mnie ze świata słyszących". [A8]

Ograniczenia medyczne a implant ślimakowy. Ograniczeń z tej kategorii dotyczy 8 ,jednostek znaczeniowych” $(12,3 \%)$. Przede wszystkim uczestnicy badań wskazują na "niemożność wykonania niektórych zabiegów i badań” [A6], np. rezonansu magnetycznego. Doświadczane objawy, które ankietowani wiążą z CI, to np. bóle głowy (2 osoby), zaburzenia smaku (1 osoba) czy szum (1 osoba). Poniżej podane zostały przykłady wypowiedzi:

- „Brak możliwości robienia niektórych badań”. [A21]

- „Skutki uboczne: ból głowy w miejscu z implantem”. [A23]

- „Utrzymujące się zaburzenia smaku”. [A9]

Koszty a implant ślimakowy. W wypowiedziach ankietowych pojawiła się kategoria kosztów związanych z korzystaniem z CI (5 „jednostek znaczeniowych”- 7,69\%), jak np. baterii. Niektórzy uczestnicy badań wyrażali zaniepokojenie o koszty związane z ewentualną awarią systemu implantu ślimakowego czy ubezpieczeniem CI, co ilustrują przytoczone przykłady:

- „Duże koszta (baterie zbyt szybko wyczerpują się)”. [A21] 


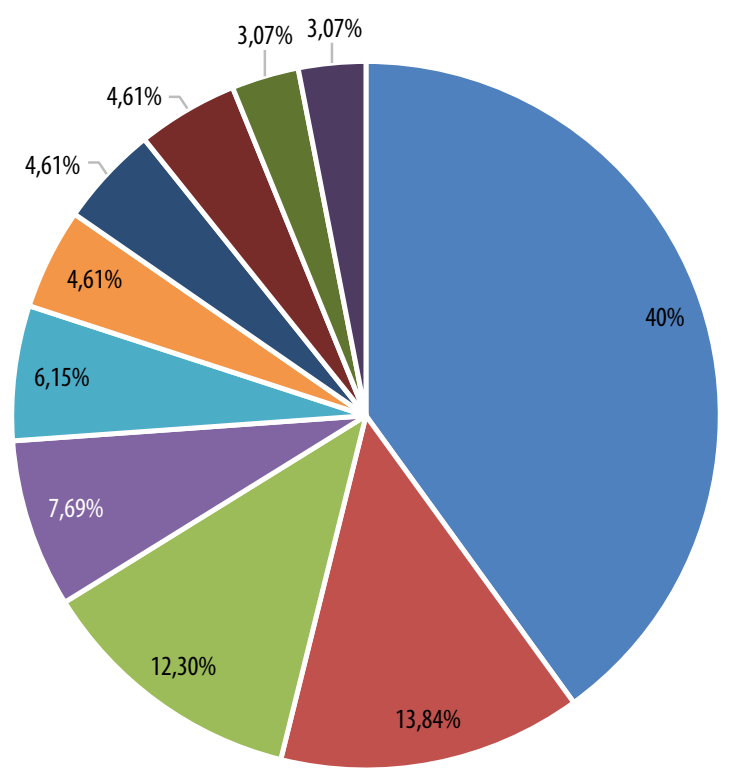

- Ograniczenia techniczno-eksploatacyjne

- Ograniczenia aktywności

- Ograniczenia medyczne

- Koszty

- Ograniczenia "słuchowe”

- Ograniczenia estetyczne

- Ograniczenia psychologiczne

- Ograniczenia rehabilitacyjne

- Ograniczenia w mowie

i komunikowaniu się

- Brak negatywnych stron

Rycina 3. Negatywne strony implantu ślimakowego $(\mathrm{Cl})$ w wypowiedziach ankietowych osób dorosłych z głuchotą prelingwalną - rozkład wypowiedzi (,jednostek znaczeniowych" - $\mathrm{n}=65$ ) według wyodrębnionych w analizie treści kategorii

Figure 3. Disadvantages of the cochlear implant $(\mathrm{Cl})$ in questionnaire for adults with prelingual deafness - distribution of utterances ("meaning units" $-n=65$ ) according to separate categories based on the content analysis

- „Koszty utrzymania, ubezpieczenia”. [A9]

- „Koszty w przypadku wystąpienia jakiejkolwiek awarii są ogromne". [A16]

Ograniczenia „słuchowe” a implant ślimakowy. Niektórzy użytkownicy CI (4 ,jednostki znaczeniowe”- 6,15\%) wymieniali zakłócenia i zniekształcenia głosu czy szum jako jego negatywne strony. Nieprzyjemne doznania opisywane były w kontekście pewnych rodzajów dźwięków i ich dużego natężenia, jak głośno pracujące maszyny, krzyczące dzieci czy nagły „pisk opon” na ulicy. Jedna osoba podzieliła się refleksją, że CI nie zapewnia „normalnego słyszenia”. Przykładowe wypowiedzi podano poniżej:

- „Są czasami dźwięki, że są głośne, czyli remont u sąsiada, koszenie trawy na ulicy”. [A20]

- „Nie jest to $100 \%$ słyszenia (ale i tak bardzo dużo!)”. [A14]

Ograniczenia estetyczne a implant ślimakowy. Niektórzy biorący udział w badaniach ( 3 ,jednostki znaczeniowe" - 4,61\%) zwracali uwagę na aspekt estetyczny implantu ślimakowego związany z jego widocznością, wielkością i ogólną estetyką. Autorzy tych wypowiedzi to młode kobiety w wieku 19, 20, 24 lata $^{3}$. Mówią o tym w swoich wypowiedziach:

\footnotetext{
${ }^{3}$ Jak pokazuje nasza wieloletnia praktyka kliniczna, mężczyźni również wyrażają troskę i „zaniepokojenie” o wygląd samego implantu ślimakowego, widoczność, cechy estetyczne, co nie ujawniło się w prezentowanych tu wypowiedziach ankietowych. Należy zauważyć, że mężczyźni stanowią 8 osób $(28,57 \%)$ w grupie uczestników badań.
}

- „Procesor mowy jest mało estetyczny”. [A12]

- „Jest widoczny”. [A14]

- „Procesor mógłby być mniejszy albo ulokowany tylko pod skórą". [A22]

Ograniczenia „psychologiczne” a implant ślimakowy. Wśród ankietowanych były osoby wskazujące na ograniczenia, które określić można jako „natury psychologicznej” (3 ,jednostki znaczeniowe" - 4,61\%). Wiązały się one $\mathrm{z}$ negatywnym odbiorem społecznym, a więc uprzedzeniami wobec osoby „z czymś na głowie” [A17]. Inna wypowiedź wyrażała obawę o niezrozumienie problemu osoby (prelingwalnie) głuchej z CI i brak świadomości ludzi, że CI nie czyni z niej osoby słyszącej, co oznacza m.in., że pomimo zaopatrzenia w CI może wciąż doświadczać różnorodnych problemów związanych ze słyszeniem, rozumieniem mowy i komunikowaniem się $\mathrm{z}$ otoczeniem (i wiele innych). W jeszcze innej wypowiedzi zawarta jest refleksja dotycząca informowania na etapie przygotowania do wszczepienia implantu ślimakowego o tym, co będzie po implantacji w sferze słyszenia i rozumienia, zwłaszcza gdy są to osoby w wieku dorastania lub dorosłe. Chodzi o subiektywnie doświadczane pogorszenie słyszenia i rozumienia mowy w porównaniu z uzyskanym wcześniej $\mathrm{w}$ aparatach słuchowych $[13,14]$. Wystąpienia różnych reakcji emocjonalnych, np. depresyjnych, po implantacji można się czasem spodziewać u osób w wieku dorastania czy dorosłych z głuchotą prelingwalną, które decydują się na CI, a co za tym idzie - przygotowanie do CI powinno obejmować też informację w tym zakresie. W tym miejscu należy jednak dodać, że osoby dorastające lub dorosłe mogą nie przyjmować pewnych informacji albo wybiórczo je spostrzegać, ponieważ znajdują się one w sytuacji emocjonalnie trudnej. Oznacza to, że mogą 
one np. uruchamiać mechanizmy obronne odpowiedzialne za zniekształcenia otrzymywanych informacji, pomimo że zostały one im przekazane przez osoby zajmujące się kwalifikacją pacjentów do CI.

- „Kiedy ktoś się dowie, że jednak słyszę, nie jest świadomy, że jest to tylko pewna namiastka słuchu, oczekuje, że będę słyszał jak inni”. [A17]

- „Brak informacji, że zaraz po wszczepieniu gorzej się słyszy niż w aparatach - skutkiem dla nastolatków mogą być stany depresyjne". [A19]

Ograniczenia „rehabilitacyjne” a implant ślimakowy. Kilku uczestników badań zwraca uwagę na różne aspekty rehabilitacji po wszczepieniu implantu ślimakowego, takie jak np. jej długotrwałość czy zazwyczaj konieczność jej prowadzenia po ewentualnej reimplantacji. Jedna osoba wyraża niespełnione oczekiwania jako użytkownika CI dotyczące efektywności implantu ślimakowego. Dotyczy to zwłaszcza tych, którzy decyzję o implancie ślimakowym podjęli jako ludzie dorośli. Poniżej podano przykłady wypowiedzi:

- „[CI] ciągła rehabilitacja”. [A21]

- „Efekty nie zawsze są rewelacyjne”. [A27]

Ograniczenia w rozumieniu mowy $\mathrm{i}$ komunikowaniu się a implant ślimakowy. Nieliczne osoby ( 2 ,jednostki znaczeniowe" - 3,07\%) wskazywały na trudności w rozumieniu mowy jako negatywną stronę CI czy utrudnienia $\mathrm{w}$ rozumieniu mowy $\mathrm{w}$ hałasie, co pokazują poniższe wypowiedzi:

- „Większość nie rozumiem mowy ludzkiej. Zmuszona jestem na czytanie z ust”. [A1]

- „Trudność rozumienia mowy w hałasie”. [A27]

Brak negatywnych stron implantu ślimakowego. Na temat braku negatywnych stron CI wypowiedziały się 2 osoby (3,07\% ogółu ,jednostek znaczeniowych”). Jedna z nich stwierdziła:

- „Nie mam żadnych negatywnych stron implantu ślimakowego". [A25]

\section{Dyskusja}

Celem przeprowadzonych badań było poznanie perspektywy, z jakiej patrzą na implant ślimakowy (CI) dorośli użytkownicy z głuchotą prelingwalną, $\mathrm{w}$ trzech aspektach: znaczenia, a także pozytywnych i negatywnych stron CI. Jak dotąd nie ma w polskim piśmiennictwie prac badawczych, zrealizowanych $\mathrm{w}$ podejściu jakościowym $\mathrm{z}$ wykorzystaniem metody analizy treści wypowiedzi ankietowych, w odniesieniu do tej grupy użytkowników CI, którzy otrzymali implant w dzieciństwie czy adolescencji bądź w okresie dorosłości.

Poddając analizie jakościowej treść wypowiedzi ankietowych użytkowników CI z głęboką głuchotą o początku prelingwalnym, otrzymano, że implant ślimakowy jest w tej grupie waloryzowany zdecydowanie bardzo pozytywnie lub pozytywnie jako posiadający bardzo duże, ogromne wręcz znaczenie, „najcudowniejszy wynalazek na świecie”, jak to określiła jedna $\mathrm{z}$ uczestniczek badań. Rezultat ten pozostaje $\mathrm{w}$ zgodności $\mathrm{z}$ innymi badaniami jakościowymi dotyczącymi młodzieży prelingwalnie głuchej korzystającej z CI z Wielkiej Brytanii [28,29] czy z indywidualnymi wypowiedziami polskich użytkowników implantu ślimakowego wszczepionego im bądź w dzieciństwie [np. 10], bądź w okresie dorosłości $[1,12]$. Osoby badane niezależnie od stopnia zadowolenia $\mathrm{z}$ implantu ślimakowego wyrażanego na skali VAS, a także wieku, w jakim otrzymały CI, pozytywnie wypowiadały się na temat znaczenia tego urządzenia dla nich. Wśród uczestników badań znalazł się jeden, którego rodzice są Głusi (i reprezentują, jak można przypuszczać, społeczność ludzi Głuchych, a sugeruje to biegła znajomość języka migowego wspomnianego uczestnika badań relacjonowana w Ankiecie). Jego pozytywna waloryzacja CI nie różni się na poziomie wyrażonych treści od tych wypowiedzi ankietowych, które pochodzą od uczestników ze słyszących rodzin, a także pozostaje w sprzeczności z poglądami wobec implantu ślimakowego reprezentowanymi przez większość społeczności ludzi Głuchych w Polsce, opisanymi w innych pracach $[20,22,37]$.

Pozytywne znaczenie implantu ślimakowego wyrażane jego słowną oceną, a także wiązane z poprawą jakości życia w poczuciu uczestników badań ma związek, jak wynika z przeprowadzonej analizy treści wypowiedzi ankietowych, przede wszystkim ze słyszeniem, „możliwością słyszenia”, „coraz lepszym słyszeniem”, łącznie z odbiorem muzyki i innych dźwięków otoczenia niedostępnych bez implantu ślimakowego, jak np. śpiew ptaków czy szum morza. Tak pozytywna waloryzacja CI i jakości życia z nim kojarzonej łączy się w wypowiedziach ankietowanych z doświadczaną prawie w równym stopniu co słyszenie możliwością (lub jej poprawą) rozumienia mowy i komunikowania się $\mathrm{z}$ innymi w języku fonicznym.

W opisie znaczenia CI, dokonywanym przez jego dorosłych użytkowników z głuchotą prelingwalną, pojawiają się zwerbalizowane emocje pozytywne, jak zadowolenie, szczęście czy radość. Uczestnicy badań nie ujawniają natomiast prawie wcale emocji negatywnych. Jednakże dość liczne wypowiedzi na temat negatywnych stron CI, dotyczące zwłaszcza eksploatacji tego urządzenia, jak np. częsta wymiana baterii, czy sporadycznie wyrażony strach o to, że przestanie działać („czuję strach, że przestanie działać”), można potraktować także jako komunikaty o doświadczeniach negatywnych związanych z CI (i głuchotą). Podobną interpretację negatywnych informacji na temat programu rehabilitacji słuchowej jako komunikatów o negatywnych doświadczeniach uczestników przyjęto w badaniach jakościowych dotyczących użytkowników aparatów słuchowych [41]. Obawy i lęk związane z zaprzestaniem działania implantu ślimakowego (awaria części zewnętrznych czy też tych wewnętrznych, co wiąże się z reoperacją) są wyrażane otwarcie przez większość młodych ludzi w wieku od 13 do 16 lat biorących udział w badaniach jakościowych na temat roli implantów ślimakowych w ich życiu, które zostały przeprowadzone w Wielkiej Brytanii [28,29]. Można więc sądzić, że wśród naszych uczestników badań są osoby, u których doświadczenie „braku słyszenia” (inaczej głuchoty) w sytuacji awarii/wyłączenia CI na jakiś czas z użycia budzi silne negatywne uczucia, od niepokoju do silnego lęku, a nawet paniki, z którymi to radzą sobie nie dość efektywnie. 
Negatywne doświadczenia z CI, o których nie ma mowy w zebranych wypowiedziach ankietowych, a pojawiają się w cytowanych wcześniej pracach, to m.in. frustracja przeżywana w interakcjach społecznych z powodu (nie) słyszenia i nierozumienia komunikatów przekazywanych drogą słuchową pomimo korzystania z CI, poczucie bycia odmiennym i poczucie izolacji wśród osób słyszących, poczucie bycia "pomiędzy” głuchymi i słyszącymi $[22,28-32,40]$ i in. Ponadto wypowiedzi ankietowe o pozytywnych i negatywnych stronach CI w całej grupie uczestników badań zawierają podobną liczbę „jednostek znaczeniowych", podczas gdy w cytowanych badaniach brytyjskich [28] proporcje wyodrębnionych w wypowiedziach młodzieży głuchej z CI stwierdzeń pozytywnych do negatywnych wyraża stosunek 9:1, co wspiera przyjętą interpretację trudności w werbalizacji doświadczeń negatywnych. Trudności w dostępie do emocji pozytywnych i negatywnych stwierdzono u głuchych młodych ludzi o wysokich kompetencjach w języku polskim fonicznym lub/i migowym we wcześniejszych badaniach [43], natomiast trudności $\mathrm{w}$ werbalizacji emocji u korzystających z implantów ślimakowych dorosłych z głuchotą prelingwalną [44].

Okazuje się też, że implant ślimakowy w doświadczeniach niektórych jego użytkowników z głuchotą prelingwalną wiąże się $\mathrm{z}$ osobistym rozwojem, byciem pewnym siebie i samodzielnym w życiu, podobnie jak w innych badaniach $[10,28,29]$. Jeszcze inni odnoszą znaczenie CI i jego pozytywne strony do relacji społecznych ze słyszącymi, co wskazuje na posługiwanie się w percepcji tych relacji opozycją głusi - słyszący, a co za tym idzie podejmują - chociaż nie wprost - problem tożsamości społecznej jako osoby głuchej. Jak wiadomo już z badań prowadzonych w krajach europejskich czy Stanach Zjednoczonych Ameryki Północnej [25,26,28-31], prelingwalnie głusi użytkownicy CI wykazują tendencję do utożsamiania się z osobami słyszącymi, a więc bycia „słyszącymi niesłyszącymi” [13] albo mają poczucie bycia „pomiędzy” osobami słyszącymi i g/Głuchymi (w sensie audiologicznym, a czasem także społeczno-kulturowym) [18,22,25,32,40]. Tożsamość społeczna osoby głuchej jako słyszącej (identyfikacja ze słyszącymi) niesie z sobą zagrożenie ukształtowania tożsamości przybranej [45], fałszywego Ja [46], jak zresztą każda inna tożsamość społeczna jako osoby głuchej. Wyróżniane w piśmiennictwie rodzaje tożsamości społeczno-kulturowej jako osoby głuchej (tożsamość słyszących, tożsamość g/Głuchych, tożsamość dualna g/ Głuchych i słyszących, tożsamość marginalna: ani g/Głuchych, ani słyszących) nie wykazują związku z dobrostanem psychicznym za wyjątkiem tożsamości marginalnej, a co za tym idzie - poczuciem braku przynależności do którejś z wymienionych grup, która to dodatnio koreluje z negatywnym samopoczuciem [26] czy nasileniem objawów depresji [27].

Warte zauważenia jest to, że uczestnicy badań, którzy w swoich wypowiedziach ankietowych nawiązywali do opozycji głusi - słyszący w zdecydowanej większości deklarowali poczucie przynależności do osób słyszących. Można powiedzieć, że w przyjętej formule badań nie mieli możliwości wypowiedzenia się na temat własnej tożsamości jako osoby głuchej, gdyż m.in. Ankieta nie zawierała pytań potencjalnie uruchamiających „treści tożsamościowe”, w tym zwłaszcza określenia siebie jako będących „pomiędzy” dwoma światami: g/Głuchych i słyszących. Należy dodać, że przyjęta formuła badań ankietowych ma swoje jeszcze inne ograniczenia, np. badani odpowiadali pisemnie z założenia "sam na sam” na pytania zawarte w Ankiecie, nie wchodzili w relację osobową $\mathrm{z}$ osobą prowadzącą te badania, mieli ograniczoną przestrzeń wypowiedzi itp. W przyszłości zatem należałoby zastąpić ją inną, tj. np. pogłębionymi wywiadami odnośnie do zagadnień zasygnalizowanych relacjonowanymi wynikami analiz treści wypowiedzi ankietowych na temat wybranych aspektów implantu ślimakowego, tj. znaczenia, jak i jego pozytywnych i negatywnych stron.

Można też powiedzieć, że uzyskane wyniki w przybliżeniu odzwierciedlają podawane przez słyszących rodziców uzasadnienia dotyczące decyzji o CI dla ich głuchego dziecka [36]. Otóż w aspekcie CI najważniejszy okazał się dla nich słuch i możliwość słyszenia przez dziecko wraz z prawidłowym jego rozwojem i normalizacją życia. Bardzo duże znaczenie, jakie przypisują w swoich wypowiedziach ankietowych słyszący rodzice, wyrażone zostaje w nadziei, wielkiej szansie czy wręcz „jedynej nadziei”, jakiej upatrują we wszczepieniu CI ich głuchemu dziecku. Z drugiej strony można zauważyć, że spełnione zostają, przynajmniej w części, pragnienia słyszącej większości, zwolenników medycznego podejścia do głuchoty jako wady, deficytu, czy niepełnosprawności, a więc ma miejsce zminimalizowanie skutków głuchoty - w tym sensie CI staje się wobec niej „,antidotum”. Jak to wyraził jeden z uczestników badań: „Nie jest to $100 \%$ słyszenia (ale i tak bardzo dużo!)”. Implant ślimakowy pomimo polaryzacji pozytywnej w percepcji jego znaczenia, jak i doświadczeń z nim związanych, na jaką wskazują rezultaty przeprowadzonych badań, nie uczyni z osoby głuchej osoby słyszącej $[11,20,22]$,

Zgłaszane w wypowiedziach biorących udział w badaniach dorosłych osób prelingwalnie głuchych z CI ograniczenia związane z tym urządzeniem, które wpisują się w obszar medyczny, dotyczą np. bólów głowy, które ankietowani przypisują CI, choć mogą mieć one inne źródła, np. podłoże psychosomatyczne, co wymaga indywidualnej wielospecjalistycznej diagnozy. Wymieniane ograniczenia $\mathrm{z}$ tej sfery to też niemożność poddania się różnym badaniom, jak rezonans magnetyczny. Dzięki najnowszym technologiom wykorzystywanym w implantach ślimakowych ograniczenia te stopniowo się zmniejszają. Istotną obserwacją jest również to, że uczestnicy badań nie wiążą dolegliwości chorobowych z korzystaniem $\mathrm{z}$ implantu ślimakowego.

Ograniczeniem badań jest także dobór do badań osób z głuchotą prelingwalną o wysokich kompetencjach w języku polskim. Równie często spotyka się bowiem korzystających z CI, których kompetencje w polskim języku fonicznym są w różnym zakresie i stopniu ograniczone. Pacjenci kwalifikowani są do leczenia tą metodą głównie na podstawie kryterium audiologicznego. Ograniczenia w rozwoju umiejętności językowych i poznawczych, które odnotowuje się w dzieciństwie i które nie zawsze można i daje się kompensować, w perspektywie działań rehabilitacyjnych utrudniają osiągnięcie dobrych efektów językowych i komunikacyjnych. 


\section{Wnioski}

- Przeprowadzone badania o charakterze jakościowym na temat implantu ślimakowego wskazują na duże lub bardzo duże subiektywnie oceniane znaczenie tej metody leczenia dla dorosłych osób z głuchotą prelingwalną, a także na doświadczanie przez nie pozytywnego wpływu CI na jakość życia.

- W obszarze efektów pooperacyjnej rehabilitacji badani podkreślają przyrost możliwości słuchowego odbioru sygnałów i mowy, a dzięki temu lepszą komunikację z otoczeniem.

- Negatywne doświadczenia związane z CI w percepcji użytkowników prelingwalnie głuchych wiążą się przede wszystkim z ograniczeniami eksploatacyjno-technicznymi urządzenia, a także z ograniczeniami w podejmowanych aktywnościach.

- Osoby dorosłe z CI najprawdopodobniej niejednokrotnie doświadczają niepokoju, obaw czy paniki w związ$\mathrm{ku} \mathrm{z}$ realnymi lub antycypowanymi obawami o przerwy w działaniu systemu CI. Należałoby wyjść im naprzeciw, proponując różne formy interwencji psychologicznej (psychoedukacja, psychoterapia, programy on-line), której celem byłoby poznanie strategii radzenia sobie z tymi sytuacjami w sposób efektywny. Proponowane postępowanie mogłoby wpłynąć na obniżenie poziomu niepokoju, lęku czy poczucia zagrożenia w związ$\mathrm{ku} \mathrm{z}$ zaprzestaniem działania systemu CI. Wobec niektórych osób dorosłych z głuchotą prelingwalną z CI wskazane byłoby omówienie, wyjaśnienie i uporządkowanie zagadnień związanych z własną głuchotą oraz tożsamością jako osoby głuchej - użytkownika CI, a co za tym idzie znalezienie optymalnych sposobów „bycia osobą głuchą" [47] z CI.

- Związek satysfakcji z implantu ślimakowego, wieku w momencie wszczepienia CI, a także tożsamości społecznej jako osoby głuchej z percepcją CI w aspekcie znaczenia oraz pozytywnych i negatywnych stron tego urządzenia wymaga dalszych pogłębionych badań jakościowych i jakościowo-ilościowych.

\section{Piśmiennictwo:}

1. Skarżyński H. Wszczep ślimakowy u osoby dorosłej z głuchotą prelingwalną. Otolaryngol Pol, 1994; 48(Supl. 15): 152-59.

2. Skarżyński H, Szuchnik J, Mueller-Malesińska M. Implanty ślimakowe - rehabilitacja. Warszawa: Stowarzyszenie CzłowiekCzłowiekowi; 2004.

3. Piotrowska A, Obrycka A, Lorens A, Skarżyński H. Implanty ślimakowe - wczoraj i dziś. Now Audiofonol, 2014; 3(4): 23-27.

4. Most T, Shrem H, Duvdevani I. Cochlear implantation in late-implanted adults with prelingual deafness. Am J Otolaryngol, 2010; 31(6): 418-23.

5. Bosco E, Nicastri M, Ballantyne D, Viccaro M, Ruoppolo G, Maddalena AI, Mancini P. Long term results in late implanted adolescent and adult CI recipients. Eur Arch Otorhinolaryngol, 2013; 270(10): 2611-20.

6. Forli, F., Turchetti, G., Giuntini, G., Bellelli, S., Fortunato, S., Bruschini i wsp. Cochlear implant in prelingually deafened oralist adults: speech perception outcomes, subjective benefits and quality of life improvement. Acta Otorhinolaryngol Ital, 2017; 37(5): 416-22.

7. Craddock L, Cooper H, Riley A, Wright T. Cochlear implants for prelingually profoundly deaf adults. Cochlear Implants Int, 2016; 17 Suppl 1: 26-30.

8. Schramm D, Fitzpatrick E, Seguin C. Cochlear implantation for adolescents and adults with prelinguistic deafness. Otol Neurotol, 2002; 23: 698-703.

9. Kosztyła-Hojna B, Moskal D. Wpływ implantu ślimakowego (CI) na proces fonacji i komfort życia pacjentów z głuchotą pre-i postlingwalną. Pol. Merkuriusz Lek, 2012; 33: 70-79.

10. Finlay L, Molano-Fisher P. 'Transforming' self and world: a phenomenological study of a changing life world following a cochlear implant. Med Health Care Philos, 2008; 11(3): 255-67.

11. Zębik J. Tożsamość osoby zaimplantowanej - czyli o sobie. W: Woźnicka E, red. Tożsamość społeczno-kulturowa głuchych. Łódź: PZG Oddział Łódzki, WSHE; 2007, s. 233-49.

12. Rostkowska J. Implant ślimakowy a młodzież z głuchotą prelingwalną. Spojrzenie okiem logopedy. W: Kobosko J, red. Młodzież głucha i słabosłysząca w rodzinie i otaczającym świecie. Warszawa: Stowarzyszenie „Usłyszeć Świat”; 2009, s. 247-51.
13. Jurkiewicz A. Nad implantem zastanawiałam się dwanaście lat. W: Kobosko J, red. Młodzież głucha i słabosłysząca w rodzinie i otaczającym świecie - dla terapeutów, nauczycieli, wychowawców i rodziców. Warszawa: Stowarzyszenie „Usłyszeć Świat"; 2009, s. 252-57.

14. Rostkowska J. Wojewódzka B. Analiza efektów terapii 51-letniego pacjenta prelingwalnie ogłuchłego zaopatrzonego w implant ślimakowy. Now Audiofonol, 2013; 2(3): 49-58.

15. Lane H. Maska dobroczynności. Deprecjacja społeczności głuchych. Tłum. Gałkowski T, Kobosko J. Warszawa: WSiP; 1996.

16. Leigh IW. A lens on deaf identities, Oxford, New York: Oxford University Press; 2009.

17. Kobosko J. Osoba głucha (słabosłysząca), to znaczy kto? - tożsamość osobowa młodzieży głuchej i słabosłyszącej rodziców słyszących. W: Kobosko J, red. Młodzież głucha i słabosłysząca w rodzinie i otaczającym świecie - dla terapeutów, nauczycieli, wychowawców i rodziców. Warszawa: Stowarzyszenie „Usłyszeć Świat"; 2009, s. 19-35.

18. Podgórska-Jachnik D. Głusi. Emancypacje. Łódź: Wydawnictwo UŁ; 2013.

19. Wojda P. Razem czy osobno? Dylematy edukacji a język „osób z uszkodzeniami narządu słuchu". W: Lejzerowicz M, Stankiewicz T, Krasnodębski M, red. Nowy nauczycie, nowa edukacja. Warszawa: Wyższa Szkoła Przymierza Rodzin; 2014, s. 31-58.

20. Potrzebka W, Moroń E, Tomaszewski P, Piekot T. Implantacja ślimakowa z perspektywy krytycznej. W: Bargiel-Matusiewicz K, Tomaszewski P, Pisula E, red. Kulturowe oraz społeczne aspekty zdrowia i obrazu ciała. Warszawa: Wydawnictwa UW; 2015, s. 67-90.

21. Wrześniewska-Pietrzak M. Aksjologiczne wyznaczniki tożsamości w wypowiedziach głuchych i czasopiśmie środowiskowym „Świat Ciszy”. Poznań: Wydawnictwo Rys; 2017.

22. Tomaszewski P. Implanty ślimakowe - etyka a wybór. Kultura-Społeczeństwo-Edukacja, w druku.

23. Krakowiak K. Dar języka. Podręcznik metodyki wychowania językowego dzieci i młodzieży z uszkodzeniami narządu słuchu. Lublin: Wyd. KUL; 2012.

24. Kobosko J. Doświadczanie siebie jako osoby głuchej - badania nad młodzieżą głuchą i jej słyszącymi matkami z perspektywy interpersonalnej. Człowiek - Niepełnosprawność - Społeczeństwo, 2010; 11: 101-122. 
25. Rich S, Levinger M, Werner S, Adelman C. Being an adolescent with a cochlear implant in the world of hearing people. Coping in school, in society and with self-identity. Int J Ped Otorhinolaryngol, 2013; 77(8): 1337-44.

26. Chapman M, Dammeyer J. The significance of deaf identity for psychological well-being. J Deaf Stud Deaf Educ, 2016; 22(2): 187-94.

27. Kobosko J. Tożsamość osób głuchych z implantem ślimakowym - wyzwania i dylematy współczesności. Referat wygłoszony na konferencji „Głusi i słabosłyszący w perspektywie tradycji, teraźniejszości i przyszłości”, Warszawa, 22-23 września 2017 r.

28. Wheeler A, Archbold S, Gregory S, Skipp A. Cochlear implants: The young people's perspective. J Deaf Stud Deaf Educ, 2007; 12(3): 303-16.

29. Hilton K, Jones F, Harmon S, Cropper J. Adolescents' experiences of receiving and living with sequential cochlear implants: An interpretative phenomenological analysis. J Deaf Stud Deaf Educ, 2013; 18(4): 513-31.

30. Wald RL, Knutson JF. Deaf cultural identity of adolescents with and without cochlear implants. Ann Otol Rhinol Laryng, 2000; 185: 87-89.

31. Spencer LJ, Tomblin JB, Gantz BJ. Growing up with a cochlear implant: education, vocation, and affiliation. J Deaf Stud Deaf Educ, 2012; 17(4): 483-98.

32. Irasiak A. Tożsamość osób z implantem ślimakowym. W: Derbis R, red. Psychologiczne konteksty jakości życia społecznego. Częstochowa: Wydawnictwo Akademii Jana Długosza; 2010, s. 371-389.

33. Zalewska M. Dziecko w autoportrecie z zamalowaną twarzą. Psychiczne mechanizmy zaburzeń rozwoju tożsamości dziecka głuchego i dziecka z opóźnionym rozwojem mowy. Warszawa: J. Santorski i CO Wydawnictwo;1998.

34. Zalewska M. Mechanizmy zaburzeń tożsamości u młodzieży głuchej mającej słyszących rodziców - kliniczne studium głuchego chłopca. W: Kobosko J, red. Młodzież głucha i słabosłysząca w rodzinie i otaczającym świecie - dla terapeutów, nauczycieli, wychowawców i rodziców. Warszawa: Stowarzyszenie „Usłyszeć Świat"; 2009, s. 78-83.

35. Kobosko J, Co to znaczy być osobą głuchą? Studia nad tożsamością osobową młodzieży głuchej ze słyszących rodzin. W: Woźnicka E, red. Tożsamość społeczno-kulturowa głuchych. Łódź: WSHE, PZG; 2007; s. 33-51.

36. Kobosko J, Geremek-Samsonowicz A, Skarżyński H. Psychologiczne uwarunkowania decyzji słyszących rodziców o implancie ślimakowym dla ich głuchego dziecka. Now Audiofonol, 2015; 4(3): 101. Abstrakt.
37. Mitchiner JC, Sass-Lehrer M. My child can have more choices. Reflections of Deaf mothers on cochlear implants for their children. W: Paludneviciene R, Leigh IW, red. Cochlear implants. Evolving perspectives. Washington DC: Gallaudet University Press; 2011, s. 71-94.

38. Kotowicz, J. Głuche dziecko z implantem ślimakowym. Propozycja dwujęzyczności migowo-fonicznej w środowisku rodzinnym i szkolnym. Rocznik Komisji Nauk Pedagogicznych, 2017; 70: 114-26.

39. Krejtz K, Krejtz I. Metoda analizy treści - teoria i praktyka badawcza. W: Stemplewska-Żakowicz K, Krejtz K, red. Wywiad psychologiczny. Wywiad jako postępowanie badawcze. Część 1. Warszawa: Pracownia Testów Psychologicznych PTP; 2005, s. $129-149$.

40. Zębik J. Tożsamość osób g/Głuchych $\mathrm{z}$ implantem ślimakowym w Polsce. W: Kobosko J, red. Młodzież głucha i słabosłysząca w rodzinie i otaczającym świecie - dla terapeutów, nauczycieli, wychowawców i rodziców. Warszawa: Stowarzyszenie „Usłyszeć Świat"; 2009, s. 45-51.

41. Malmberg M, Sundewall-Thorén E, Öberg M, Lunner T, Andersson G, Kähäri K Experiences of an Internet-based aural rehabilitation (IAR) program for hearing aid users: a qualitative study. Int J Audiol, 2018; 1-7. [Epub ahead of print]

42. Eisenberg L. Use of the cochlear implant by prelingually deaf. Ann Otol Rhinol Laryngol Suppl, 1982; 91: 62-66.

43. Kobosko J. Gdzie jest moje prawdziwe Ja(self)? Świat emocji młodzieży głuchej ze słyszących rodzin. W: Krakowiak K, Dziurda-Multan A, red. Nie głos, ale słowo... Ku wspólnocie komunikacyjnej niesłyszących i słyszących. Lublin: Wydawnictwo KUL; 2011, s. 81-95.

44. Kobosko J. Spostrzeganie wsparcia emocjonalnego a jakość relacji z innymi ludźmi u osób z głuchotą prelingwalną. W: $\mathrm{Pa}-$ rys K, Pasteczka M, Sikorski J, red. Teoria i praktyka oddziaływań profilaktyczno-wspierających rozwój osób z niepełnosprawnością - konteksty indywidualne i środowiskowe, t. 4.2. Kraków: Wydawnictwo Uniwersytetu Pedagogicznego; 2017, s. 221-37.

45. Marcia J. Development and validation of ego identity status. J Personal Soc Psychol, 1966; 3: 551-58.

46. Winnicott DW. Dziecko, jego rodzina i świat. Tum. Bartosiewicz A. Warszawa: J. Santorski i CO Wydawnictwo;1993.

47. Ohna ES. Deaf in my own way: Identity, learning and narratives. Deafness and Education International, 2004; 6(1): 20-37. 